\title{
RELACIJE KVALITETA RODITELJSKOG SAVEZA I FUNKCIONALNOG STATUSA DETETA: PROCENA OČEVA I MAJKI*
}

Rad se bavi odnosom kvaliteta koroditeljske saradnje i funkcionalnog statusa deteta $\mathrm{u}$ porodicama dece predškolskog uzrasta koja su u periodu istraživanja prvi put pošla u vrtić. Polazak u vrtić predstavlja razvojnu krizu za porodicu koja može remetiti i menjati funkcionisanje porodičnih odnosa i funkcionalni status deteta. U radu je prikazana povezanost koroditeljske saradnje, opisane preko snage roditeljskog saveza i regulatorskog ponašanja majke, i procene funkcionalnog statusa deteta od strane očeva i majki. Rezultati su diskutovani u odnosu na dosadašnja istraživanja koja su se bavila značajem roditeljskih relacija za detetov razvoj i blagostanje. Dobijeni nalazi ukazali su na značaj rada na koroditeljskoj saradnji u smislu prevencije regulatorskog ponašanja majki što bi vodilo većoj senzitivnosti roditelja i kvalitetnijoj brizi o detetu.

Ključne reči: koroditeljska saradnja, roditeljski savez, regulatorsko ponašanje majke, funkcionalni status deteta

Značaj roditeljstva i porodice za razvoj deteta, prilagođavanje i njegov zdravstveni status je široko istraživano polje. Odgovor na pitanje koji to faktori porodice utiču na razvoj deteta i njegovo blagostanje je složen i odbuvata varijable koje se mogu najopštije podeliti na strukturne i procesne karakteristike porodice. Mnogobrojni nalazi ukazuju na karakteristike porodice koje štite i podstiču razvoj deteta, ali i na one koje su rizične i imaju nepovoljne efekte po dete, kao i na veliku isprepletenost ovih efekata i činilaca. Koroditeljska saradnja jedan je od aspekata porodičnog funcionisanja odnosno roditeljskog ponašanja čiji su značaj za razvoj i blagostanje deteta potvrdili brojni nalazi. Studije su ukazale da će pozitivna interakcija roditelja sa detetom, doslednost i efektivno roditeljstvo biti povezani sa kognitivnim, socijalnim, bihejvioralni i psihosocijalnim postignućima deteta. Pored individualnih karakteristika roditeljstva, odnosno roditeljskog ponašanja, istraživanja ukazuju upravo na značaj kvaliteta relacije među roditeljima tačnije koroditeljske saradnje (roditeljskog saveza ili alijanse) za detetov razvoj, ponašanje, blagostanje i prilagođavanje u situacijama stresa (Abidin \& Brunner, 1995; Blesky, Putnam \& Crnic, 1996; Konold \& Abidin, 2001; Blesky, Bell, Bradley,

* imihic@ff.uns.ac.rs 
Stallard \& Stewal-Brown 2006; Blesky et al., 2007; Teubert \& Pinquart, 2010; Garner et al. 2011).

Weissman i Cohen (1985, prema Abidin \& Brunner, 1995), tvorci koncepta roditeljskog saveza, definisali ovaj odnos supružnika preko transakcija i interakcije između odraslih odnosno oba roditelja i deteta. Ovi autori roditeljsku alijansu opisuju preko tri domena: posvećenost detetu od strane oba roditelja, međusobna podrška u vaspitavanju deteta (poštovanje supružnikovog vaspitanog stila) i međusobna komunikaciju u funkciji upravljanja porodicom. Istraživanja ukazuju da će posvećenost majki i očeva roditeljskoj ulozi voditi jakom roditeljskom savezu (Abidin \& Brunner, 1995). Feinberg (2003) nešto drugačije definiše koroditeljstvo opisujući ga preko četiri dimenzije: slaganje/neslaganje oko pitanja vezanih za odgajanje deteta, podela posla u vezi sa podizanjem deteta, podrška koroditelju i zajedničko upravljanje porodičnim interakcijama. Ovako operacionalizovana koroditeljska saradnja bliža je sistemskoj teoriji i ukazuje na aspekt partnerske relacije koji je upravo zadužen za zajedničku brigu o detetu i porodici (Mihić, 2009). Roditeljski savez reflektuje se u interakciji i zajedničkom podizanju dece i treba ga razlikovati od individualnog roditeljskog stila (Teubert \& Pinquart, 2010). Sa aspekta sistemske teorije roditeljski savez se razvija unutar roditeljskog subsistema i ima izvršnu ulogu u roditeljstvu, reguliše porodične relacije i u funkciji je blagostanja deteta. Savez stoga podrazumeva zajedničko i deljeno upravljanje porodičnim sistemom, postavljanje pravila i granica, kontrolu, brigu o deci i regulisanje interkacija unutar porodice (Minuchin, 1985; Miljković, Srna \& Mićović, 1997; Margolin, Gordus \& John, 2001). Istraživanja kvaliteta odnosno snage roditeljskog saveza pokazala su da se između majki i očeva mogu naći značajne razlike u proceni kvaliteta koroditeljske saradnje. Ove razlike se uglavnom objašnjavaju posvećenošću roditelja rodnim ulogama. Tako će na primer žene češće, bez obzira na zadovoljstvo brakom, biti aktivno uključene u brigu o detetu, dok će muškarci, posebno ako nisu zadovoljni bračnom relacijom, češće biti manje uključeni u roditeljstvo (Abidin \& Bruner, 1995). Uključenost oca u brigu o detetu, kao aspekt funkcionalnog roditeljskog saveza, objašnjava se i nekim drugim faktorima, kao što je na primer, percepcija roditeljske uloge oca od strane majki, podrška koju supruge daju roditeljstvu očeva, ali i regulatorsko ponašanje majki (McBride \& Rane, 1998; Mihić, 2010a). Regulatorsko ponašanje majki odnosi se na one oblike ponašanja kojima majka inhibira saradnju sa ocem u sprovođenju brige oko porodice i deteta. Na ovaj način majke ograničavaju uključivanje očeva u staranje o detetu i hendikepiraju ga u učenju i sticanju iskustva o roditeljstvu. Regulatorska pozicija ili ponašanje majki smatra se specifičnim oblikom funkcionisanja unutar roditeljskog saveza koji reflektuje njegovu funkcionalnost i predstavlja oblik borbe za moć u poziciji dominirajućeg roditelja (Allen \& Hawkins, 1999; Mihić 2010a; Mihić 2010b; Mihić 2010c).

Poslednjih 20 godina istraživanja su pokazala da je kvalitet koroditeljske relacije značajan faktor za razvoj od perioda odojčeta do kasne adolescencije (Teubert \& Pinquart, 2010). Kvalitet roditeljskog saveza ima jači uticaj na prilagođavanje 
deteta nego bilo koji drugi aspekt partnerske relacije (Abidin \& Brunner, 1995; Feinberg, 2003) i može da ostvari efekte na razvoj deteta nezavisno od samog kvaliteta bračnog odnosa (Feinberg, 2003). Ukoliko je savez dobar roditelji će biti uspešni u negovanju deteta, čak i onda kada su u pitanju razvedeni partneri. Usklađenom saradnjom roditelja i doslednim odgovaranjem na detetove razvojne potrebe smajuje se rizik od javljanja problema u detetovom zdravlju i funkcionisanju (Abidin \& Brunner, 1995; Konold \& Abidin, 2001). U nekliničkom uzorku, kod porodica u kojima je roditeljska alijansa snažna neće se javiti negativni efekti porodičnog stresa po razvoj deteta, što se objašnjava protektivnim uticajem roditeljskog saveza (Abidin \& Brunner, 1995).

Nalazi istraživanja koja ispituju povezanost kvaliteta roditeljskog saveza sa pozitivnim napredovanjem i kompetencijama deteta uglavnom su konzistentni i govore u prilog značaju jake koroditeljske saradnje za detetov razvoj. Neslaganje među roditeljskim vaspitnim postupcima biće povezano sa promenama u ponašanju dece u predškolskom uzrastu (Block, Block \& Morrison, 1981; Deal et al., 1989, prema Abidin \& Brunner, 1995), ali i adolescenciji (Feinberg, 2003). Pored toga, dosadašnje studije ukazale su na to da su kvalitet roditeljstva i relacije roditelj - dete potencijalne determinante zdravlja deteta (Blesky et al., 2006). Razvojne studije čak sugerišu da će ovi aspekti porodičnog sistema biti važni za psihičko i fizičko zdravlje potomaka i u odraslom dobu (Blesky et al., 2006; Vandell et al., 2010). Takođe, nađeno je i da je kvalitet roditeljstva medijator efekta socioekonomskih varijabli na zdravlje dece što ide u prilog ideji o protektivnoj ulozi roditeljskog saveza unutar porodičnog sistema (Blesky et al., 2006). Istraživanja pokazuju da će percepcija koorditeljske podrške i nizak nivo podrivajućeg ponašanja u odnosu na roditeljsku ulogu partnera biti povezano sa problemima $u$ ponašanju dece na ranom uzrastu. Pokazalo se da će deca češće ispoljavati probleme u ponašanju ukoliko njihovi roditelji procenjuju da njihov partner ne podržava njihovo roditeljsko ponašanje te podriva njihovu roditeljsku ulogu. Ova veza je posebno jaka kada se analizira podržavajuće ponašanje majki prema roditeljskoj ulozi oca (Lerpoy, Mahoney, Demaris \& Pargamnet, 2013).

Longitudinalna istraživanja koja su se bavila značajem uključenosti oca za detetov razvoj nalaze da postoje pozitivni efekti veće uključenosti oca na razvoj deteta. Deca čiji su očevi više uključeni u brigu oko njih imaće manje bihejvioralnih problema u adolescenciji, bolje socijalne kompetencije u detinjstvu i odraslom dobu, ali i bolja obrazovna postignuća (Sarkadi, Kristiansson, Oberklaid \& Bremberg, 2007). Nedovoljna uključenost oca ili njegovo odsustvo sa druge strane biće povezano sa poteškoćama dece u ostvarivanju relacija sa vršnjacima, ali i sklonošću ka vršnjačkom nasilju (Laumann-Billings \& Emery, 1998, prema Geddes, 2008).

U istraživanju predstavljenom ovim radom bavili smo se relacijom kvaliteta koroditeljske saradnje i procena funkcionalnog statusa deteta kod očeva i majki dece predškolskog uzrasta. Nalazi ranijih istraživanja na našoj populaciji ukazuju da je kvalitet roditeljskog saveza povezan sa psihosocijalnim zdravljem i prisustvom 
hroničnih zdravstvenih problema. Slabija koroditeljska saradnja povezana je sa lošijim psihosocijalnim zdravljem i prisustvom većeg broja zdravstvenih problema kod deteta. Autori pomenutog istraživanja nisu ispitavali smer povezanosti, pa ne diskutuju o kauzalnosti ove veze (Erdeš - Kavečan, 2009). Druga istraživanja pak ukazala su da neadekvatna saradnja roditelja ne predstavlja direktan razlog za hronično oboljevanje, već da lošiji uslovi života mogu dovesti do smanjenih kapaciteta roditelja da vodi računa o zdravlju svog deteta (Conger et al., 1992). Sa druge strane, autori pomenutog istraživanja sprovedenog kod nas sugerišu da bi uočena povezanost takođe mogla biti proizvod pada kvaliteta koroditeljske saradnje usled kumulativnog efekta roditeljskog stresa u situaciji kad je dete hronično bolesno ili fizički vulenarbilno (Erdeš - Kavečan, 2009).

Za razliku od varijable hronične bolesti ili psihofizičkog zdravlja, funkcionalni status deteta pre je pokazatelj kvaliteta detetovog funkcionisanja nego što je mera zdravlja ili stanja invalidnosti. Ipak, istraživanja pokazuju da funkcionalni status značajno korelira sa zdravstvenim stanjem i objektivnim kliničkim procenama zdravstvenog statusa deteta (Stein \& Jessop, 1990). Procena funkcionalnog statusa reflektuje ograničenost detetove sposobnosti da učestvuje u svakodnevnim aktivnostima u odnosu na zdravlje i/ili invalidnost (Palermo et al., 2008). Ona deca čije su sposobnosti ometane i koja imaju poteškoće da u potpunosti nesmetano učestvuju u svakodnevnim aktivnostima imaće nizak nivo funkcionalnog statusa (Stein \& Jessop, 1990). Roditeljska koperacija daje jedinstven doprinos opisu detetovog funkcionalnog statusa. Kvalitet koroditeljske saradnje dobro predviđa ishode detetovog razvoja i promene u detetovom funkcionisanju (Teubert \& Pinquart, 2010).

S obzirom da u poslednjih nekoliko decenija istraživači ukazuju na značaj porodičnih relacija za detetovo funkcionisanje u ovom radu smo se pitali kakva je relacija kvaliteta koroditeljske saradnje i funkcionalnog statusa dece predškolskog uzrasta. Kvalitet koroditeljske saradnje definisali smo preko snage roditeljkog saveza. Kod očeva smo kvalitet koroditeljske saradnje operacionalizovali i preko regulatorskog ponašanja majki s obzirom da je ono i odraz i činilac očeve uključenosti u brigu. Pošli smo dakle od pretpostavke da postoji značajna povezanost između kvaliteta koroditeljske saradnje koju opažaju majke i očevi i njihove procene funkcionalog statusa deteta koje je tekuće godine pošlo u vtić. Cilj istraživanja je bio da se opiše veza između procena snage roditeljskog saveza i regulatorskog ponašanja majki sa procenama detetovog funkcionalnog statusa od strane majki i očeva.

\section{METOD}

\section{Procedura}

Istraživanje je sprovedeno u pet predškolskih ustanova. Stručni saradnici distribuirali su upitnike vaspitačima, a vaspitači roditeljima dece koja su tekuće školske godine po prvi put pošla u vrtić. Ispitanici su uz bateriju dobili i pismo saglasnosti u kojem su obavešteni o ciljevima i nameni istraživanja. Parovima je 
dato uputstvo da zasebno popunjavaju upitnike, kao i da se oni upitnici koji se odnose na procenu deteta popunjavaju u odnosu na ono dete koje je iste godine po prvi put upisano u vrtić.

\section{Uzorak}

Uzorak je činilo 163 roditelja, 82 majke i 81 otac. U uzorku je bilo 78 parova koji su j popunili bateriju instrumenata, 4 majke i 3 oca čiji supružnici nisu popunili upitnike. Dužina braka roditelja uključenih u uzorak bila je u proseku oko 6 godina. Raspon se kreće od 2 do 25 godina. Većina roditelja ima po dvoje dece (89, 5\%), a znatno manji procenat ispitanika ima troje i četvoro.. Od ukupnog broja ispitanika 13 majki i 11 očeva imaju decu koja su uključena u vrtić po inkluzivnom programu, dakle imaju hronično oboljenje, invaliditet ili pripadaju drugoj marginalizovanoj grupi. Više od polovine ispitanih majki i očeva bilo je zaposleno (75,6\% majki i 82,7\% očeva). Najveći broj ispitanih roditelja ima završenu srednju školu (64,9\% majki i 75,7\% očeva).

\section{Instrumenti}

Snaga roditeljskog saveza (PAM - Parenting Aliance Measure; Abidin, Konold, 1999) je skala koja sadrži 20 ajtema koji opisuju različite forme roditeljske koperacije. Zasniva se na teorijskom konceptu roditeljskog saveza Weissman-a i Cohen-a. Upitnik predstavlja meru roditeljeve procene o snazi roditeljskog saveza (koroditeljske saradnje). Tvrdnje opisuju interakcije drugog roditelja sa detetom, usklađenost vaspitnih postupaka i ciljeva, kao i međusobnu podršku u roditeljstvu. Ispitanici na petostepenoj skali procenjuju koliko se slažu sa navedenom trvdnjom, odnosno koliko ih određena trvdnja opisuje (u potpunosti se slažem sa tvrdnjom; u principu se slažem; nisam siguran; u principu se ne slažem; izrazito se ne slažem). Niži skorovi predstavljaju slab i neadekvatan roditeljski savez, dok viši ukazuju na dobar kvalitet i potencijal za podršku i zajedništvo u roditeljskoj ulozi. Teorijski minimum na skali je 20, a maksimum 100 skorova. Dosadašnja istraživanja ukazala su na dobre metrijske karakteristike ovog instrumenta i njegovu široku primenjivost u teorijske i kliničke svrhe. Instrument je proveren i na uzorku u Srbiji i nalazi su ukazali na njegovu primenjivost i u našoj populaciji. PAM se primenjuje kao jednofaktorski instrument, mada neka istraživanja ukazuju na njegovu dvofaktorsku strukturu koja opisuje dva aspekta saveza jedan koji se odnosi na samu komunikaciju i saradnju sa drugim roditeljem i drugi koji se odnosi na poštovanje roditeljske uloge partnera (Abidin \& Brunner, 1995; Konold \& Abidin, 2001; Mihić, 2009). U našem istraživanju koristili smo se jednofaktorskim rešenjem. Pouzdanost skale na našem uzorku merena Kronbahovom alfom iznosi 0,94.

Regulatorsko ponašanje majki mereno je ček listom regulatorskog ponašanja majke - RPM (Mihić, 2010a). Ček listu čini jednaest stavki kojima se opisuju ponašanja majke koja govore o podeli brige o detetu i procenjenoj neravnoteži u kompetentnosti za ispunjavanje uloge roditelja između očeva i majki. Ček listu 
popunjavaju očevi na osnovu čijih procena se dobija mera koja govori u kojom stepenu njihove supruge regulišu njihovu uključenost u staranje o detetu. Primeri stavki su: Upućuje kritike na način na koji ste nešto uradili oko deteta; Ona planira, raspoređuje i organizuje brigu o detetu, Pred Vama se ponaša kao da ste joj pomagač u svakodnevnoj brizi o detetu. itd. Procena se vrši na petostepenoj skali (stalno, četo, ponekad, retko, nikad). Teorijski minimum iznosi 11, a maksimum 55 skorova. Viši skorovi na ovoj skali ukazuju na izraženije regulatorsko ponašanje kod majke. Dobijena pouzdanost na našem uzorku merena Kronbahovom alfom je niža nego u prethodnim istraživanjima (Mihić, 2010a) i iznosi 0,54.

Upitnik za procenu funkcionalnog statusa (FS II(R) - Functional Status II(R); Stein, Jessop, 1990) se primenjuje u proceni funkcionalnog statusa deteta, a pogodan je za uzrast do 16 godina i posebno se smatra korisnim u proceni funkcionalnog statusa dece sa hroničnim tegobama, koje nisu posledica kašnjenja u razvoju. Upitnik ima dužu i kraću verziju i sastoji se iz dva dela. U istraživanju smo koristili kraću verziju upitnika od 14 stavki. Svaka stavka predstavlja izjavu kojom se opisuje zdravstveno i fizičko stanje deteta na različitim indikatorima: ishrana, spavanje, ponašanje. Primeri stavki su: Jede dobro, Spava dobro, Izgleda zadovoljno itd. Na prvom delu upitnika ispitanici na trostepenoj skali (nikad ili retko; ponekad; skoro uvek) procenjuju koliko opisano stanje odgovara stanju njihovog deteta. Drugi deo upitnika odnosi se na procenu povezanosti detetovog funkcionalnog statusa sa bolešću, ili aktuelnim stanjem stresa. Roditelji na trostepenoj skali (u potpunosti; delimično; uopšte ne) daju ocenu koliko je određeno stanje posledica bolesti (Stein \& Jessop, 1990). Viši skor govorio o boljem funkcionalnom statusu, a posredno i do izvesne mere, i boljem zdravlju deteta (Palermo et al., 2008; Stein \& Jessop, 1990). Teorijski maksimum na skali je 28. Prema istraživanjima koja se bave procenama i merama zdravstvenog statusa za malu decu procena roditelja smatra se dovoljno relijabilnim i validnim izveštajem o detetovom funkcionalnom statusu (Palermo et al., 2008). Ova mera dobro razlikuje zdrave od bolesne dece i kada razlike nisu velike, jer deca sa hroničnim problemima mogu da funkcionišu na nivou zdrave dece. Iako je ovo mera kvaliteta detetovog funkcionisanja, pre nego što je objektivna mera zdravlja ili stanja invalidnosti, istraživanja su pokazaja da je visoko povezana sa tradicionalnim merama zdravlja i blagostanja (Stein \& Jessop, 1990). Provere ovog instrumenta pokazale su da je ovo mera koja se uklapa u kriterijume za indikaciju zdravstvenog statusa, te da instrument ima dobru validnost (Palermo et al., 2008; Stein \& Jessop, 1990). Na našem uzorku dobijena pouzdanost izražena Kronbahovom alfom iznosi 0,76 .

\section{REZULTATI}

\section{Roditeljski savez}

U cilju ispitivanja razlika u proceni kvaliteta roditeljske alijanse između majki i očeva primenjen je t test za nezavisne uzorke. Rezultati su pokazali da ne postoji statistički značajna razlika u proceni kvaliteta roditeljskog saveza između 
majki i očeva $(t=1,78, p>0,05)$. Iako dobijene prosečne vrednosti ukazuju da očevi procenjuju kvalitet roditeljskog saveza nešto višim u odnosu na majke ne možemo govoriti o značajnoj razlici u proceni snage roditeljskog saveza. Dobijene vrednosti su visoke i ukazuju da i majke i očevi procenjuju da imaju dobar koroditeljski odnos sa partnerom (tabela 1).

Tabela 1. Prosečna vrednost i mera disperzije vrednosti procena kvaliteta roditeljskog saveza

\begin{tabular}{|l|c|c|}
\hline & Aritmetička sredina & Standardna devijacija \\
\hline Majke & 85,68 & 11,8 \\
\hline Očevi & 88,63 & 10,1 \\
\hline
\end{tabular}

Procena funkcionalnog statusa deteta

Deskriptivna analiza podataka pokazuje da su procene funkcionalnog statusa deteta u okviru srednjih vrednosti u odnosu na teorijski maksimum (tabela 2). U cilju ispitivanja razlika u proceni funckionalnog statusa deteta koje je tekuće godine prvi put pošlo u vrtić između majki i očeva primenjen je $t$ test za nezavisne uzorke. Rezultati su pokazali da ne postoji statistički značajna razlika u proceni funkcionalnog statusa deteta između majki i očeva $(t=3,0, p>0,05)$. Dobijene prosečne vrednosti procene funkcionalnog statusa deteta su približne, a s obzirom i da nisu nađene statistički značajane razlike možemo reći da očevi i majke jednako procenjuju funkcionalni status deteta.

Tabela 2. Prosečne vrednosti i mera raspršenja vrednosti procena funkcionalnog statusa deteta

\begin{tabular}{|l|c|c|}
\hline & Aritmetička sredina & Standardna devijacija \\
\hline Majke & 10,48 & 2,1 \\
\hline Očevi & 9,74 & 2,8 \\
\hline
\end{tabular}

Relacije kvaliteta koroditeljske saradnje i funkcionalnog statusa deteta

Majke. Kao mera kvaliteta koroditeljske saradnje kod majki uzeta je procena snage roditeljskog saveza. Kako bi se proverilo postoji li povezanost između kvaliteta koroditeljske saradnje i funkcionalnog statusa deteta analizirana je jednostavna korelacija između procene snage roditeljskog saveza i procena funkcionalnog statusa deteta. Rezultati su pokazali da ne postoji statistički značajna povezanost između procena snage roditeljskog saveza i procene funkcionalnog statusa deteta kod majki $(\mathrm{r}=0,07, \mathrm{p}>0,05)$.

Očevi. Kvalitet koorditeljske saradanje za očeve izražen je preko procene snage roditeljskog saveza i izraženosti regulatorskog ponašanja majke odnosno njihovih supruga (tabela 3). U cilju provere relacija kvaliteta koroditeljske saradnje i funk- 
cionalnog statusa deteta kod očeva primenjene su jednostavne korelacije. Analiza rezultata povezanosti snage roditeljskog saveza i procene funkcionalnog statusa deteta ukazala je na to da ne postoji statisički značajne relacije $(r=-0,06, p>$ 0,05 ). Analiza rezultata korelacije regulatorskog ponašanja majke i procene funkcionalnog statusa deteta pokazala je da postoji statistički značajna povezanost $(\mathrm{r}=$ $-0,26, p<0,05$ ). Dobijeni nalazi ukazuju na to da je kod očeva procena funkcionalnog statusa deteta značajno povezana sa regulatorskim ponašanjem majke. Dobijena povezanost je negativna što znači da će očevi čije supruge imaju izraženije regulatorsko ponašanje procenjivati da njihovo dete ima niži funkcionalni status.

Tabela 3. Prosečna vrednost i mera disperzije vrednosti procena regulatorskog ponašanja supruga kod očeva

\begin{tabular}{|l|c|c|}
\hline & Aritmetička sredina & Standardna devijacija \\
\hline Regulatorsko ponašanje majke & 27,8 & 5,1 \\
\hline
\end{tabular}

Analiza rezultata pokazala je da kvalitet koroditeljske saradnje izražen preko snage roditeljskog saveza nije značajno povezan sa procenama funkcionalnog statusa deteta ni u poduzorku majki ni očeva dece predškolskog uzrasta koja su po prvi put pošla u vrtić. Ipak, regultorsko ponašanje majki kao oblik funkcionisanja unutar roditeljskog saveza pokazalo se kao statistički značajno povezano sa procenama funkcionalnog statusa deteta kod očeva. Dobijena povezanost ukazuje na to da će očevi iz porodica sa višim regulatorskim ponašanjem majki procenjivati da imaju decu sa nižim funkcionalnim statusom u odnosu na očeve čije supruge su manje sklone uzimanju regulatorske pozicije unutar koroditeljske saradnje.

\section{DISKUSIJA}

$\mathrm{U}$ ovom radu bavili smo se ispitivanjem povezanosti snage i funkcionalnosti roditeljske saradnje sa funkcionalnim statusom deteta prema proceni očeva i majki. Dosadašnja istraživanja ukazala su na značaj kvaliteta kooroditeljske saradnje za razvoj i blagostanje deteta (Abidin \& Brunner, 1995; Blesky, Putnam \& Crnic, 1996; Konold \& Abidin, 2001; Erdeš - Kavečan, 2009; Teubert \& Pinquart, 2010) te smo pošli od pretpostavke da će značajna povezanost biti uočljiva između opisanog kvaliteta roditeljske koperacije i funkcionalnog statusa deteta. Uzorak su činili roditelji čija su deca prvi put upisana u vrtić tekuće školske godine. Opredeli smo se za uzorak koji obuhvata decu koja su tek pošla u vrtić, jer polazak u vrtić predstvlja razvojnu krizu za porodicu koja može da remeti i menja fukncionisanje porodičnih odnosa i funkcionisanje samog deteta (Minić, 2009; Velikić, Filipović, Bačić \& Bogosanović 2010; Stojić, Divljan \&Avramov 2010). Uzorkom su dakle obuhvaćene one porodice čija su deca bila na adaptaciji na vrtić u godini kad je sprovedeno istraživanje pa se može reći da je načelno uzorak bio ujednačen prema uzrastu dece i razvojnoj krizi odnosno zadacima porodice. 
Dobijeni rezultati su pokazali su da se majke i očevi ne razlikuju značajno kada je u pitanju procena kvaliteta odnosno snage roditeljskog saveza. Istraživanje Abidina i Brunera (1995) ukazuje na razlike između majki i očeva u proceni kvaliteta koroditeljske saradnje. Ovu razliku autori objašnjavaju posvećenošću roditelja rodnim ulogama (Abidin \& Bruner, 1995). Naši rezultati ne idu u prilog ovim nalazima, što ne znači da su u našoj kulturi zastupljenije egalitarne vrednosti. Naprotiv, istraživanja pokazuju jasne i čvrste tradicionalne porodične vrednosti i roditeljske uloge u našem društvu (Mihić, Zotović \& Petrović, 2007). Moguće je da dobijeni rezultati našeg istraživanja pre odražavaju karakteristike uzorka $\mathrm{s}$ obzirom da su većinu ispitanika činili parovi i da postoji mogućnost da su ipak zajedno popunjavali upitnike te nisu dobijene značajne razlike u procenama. Takođe, moguće je i da roditelji u ovom razvojnom periodu na sličan način doživljavaju kvalitet korditeljske saradnje. Dobijene prosečne vrednosti procena snage roditeljskog saveza su visoke i blizu maksimalnog skora što bi govorilo da i majke i očevi procenju koroditeljsku saradnju sa supružnikom kao visoko kvalitetnu. Da li su dobijene vrednosti procena snage roditeljskog saveza produkt „ulepšavanja” realnosti ili smo uzorkom uspeli da obuhvatimo visoko funkcionalne roditeljske parove ostaje otvoreno pitanje. Ipak, procena kvaliteta koroditeljske saradnje i u ranijim istraživanjima na našoj populaciji, bez obzira na uzrast deteta i razvojnu fazu, dosledno je $u$ domenu visoko funkcionalnih sa tendencijom da su nešto kritičnije majke, pa dosledno daju niže procene kvaliteta ove relacije (Mihić, 2006; Mihić, Zotović \& Petrović, 2007; Mihić, Zotović, Petrović \& Avić, 2009; Mihić, 2010a) što je bio slučaj i ovom istraživanju.

Nalazi našeg istraživanja nisu pokazali značajne razlike u proceni funkcionalnog statusa deteta između majki i očeva. Ovakav rezultat mogao se očekivati ako se uzme u obzir da je u pitanju procena koja se zasniva na vidljim karakteristikama i ponašanju deteta, pa je tako moguće da i majke očevi imaju sličnu procenu funkcionisanja svog deteta. U uzorak su uglavnom bila uključena deca koja nemaju poteškoće u učestvovanju u svakodnevnim aktivnosti te su dobijene srednje vrednosti funkcionalnog statusa dece u odnosu na teorijski maksimum očekivane.

Glavna pretpostavka ovog istraživanja bila je da postoji povezanost između snage roditeljskog saveza i funkcionalnog statusa deteta. Odlučili smo se da za procenu blagostanja odnosno funkcionisanja deteta uzmemo meru koja reflektuje detetovu ometenost da učestvuje u svakodnevnim ativnostima. Pošli smo od toga da je ovo dobra mera koja razlikuje zdravu od bolesne dece i kada razlike nisu velike i koja govori o nivou funkcionisanja deteta (Palermo et al., 2008; Stein \& Jessop, 1990). Na ovaj način hteli smo da ispitamo povezanost porodičnih karakteristika sa funkcionalnošću dece bez obzira na to da li imaju i koju vrstu invaliditeta ili bolesti, a u kontekstu razvojne krize, koja, stresom koji po dete nameće, izaziva određeni nivo promena u svakodnevnom funkcionisanju kao deo procesa prilagođavanja na očekivane razvojne promene.

Dobijeni rezultati ukazali su da nema značajne povezanosti kvaliteta koroditeljske saradnje i funkcionalnog statusa deteta ni kod majki ni očeva. To bi zna- 
čilo da će koroditeljsko funkcionisanje biti nezavisno od procene kvaliteta funkcionisanja deteta. Ipak, pojedini elementi funkcionalnosti koroditeljskog odnosa značajno su povezani sa procenom funkcionalnog statusa deteta. Naime, očevi iz porodica u kojima postoji izraženije regulatorsko ponašanje majki, procenjuju nižim funkcionalni status svog deteta. Regulatorsko ponašnje majki se odnosi na ona ponašanja majke koja ograničavanju uključenost oca u brigu o detetu (Mihić, 2010a; Mihić, 2010c) i predstavlja oblik takozvanog kompetitivnog koroditeljskog odnosa. Ovi se roditelji nadmeću za ulogu „boljeg”, a majke, često zahvaljujući kulturnom normiranju roditeljskih uloga, dobijaju status ,,vodećeg” roditelja, onog čija je uloga primarnija i ko određuje načine brige. U ovim porodicama majke neretko zaista i mnogo više brinu o svojoj deci, i u smislu okupiranosti roditeljskom ulogom, i u smislu vremena i obaveza koje oko deteta obavljaju. One, takođe, istovremeno opravdavaju očevu nisku uključenost i zahtevaju veće učešće uz konstantno nezadovoljstvo načinom očevog uključivanja u brigu o detetu. Unutar ovih porodica neretko postoji i visoko neslaganje u vaspitnim stilovima roditelja, vremenu i oblicima aktivnosti u kojima sa detetom učestvuju i slično (de Luccie, 1995; Allen \& Hawkins, 1999; Fagan \& Barnett, 2003; Gaunt, 2008; Cannon, Schoppet - Sullivan, Mangelsdorf, Brown \& Sokolowski, 2008). Rezultati ovog istraživanja mogli bi da ukazuju na to da će deca iz onih porodica u kojima očevi imaju više mogućnosti da budu uključeni u brigu imati bolji funkcionalni status. Moglo bi se postaviti pitanje da li manja uključenost oca vodi lošijoj mogućnosti procene aktuelnog načina funkcionisanja deteta, a ne realno nižem funkcionalnom statusu. Možda očevi koji su značajno uskraćeni za iskustvo brige u odnosu na očeve koji više učestvuju u njoj procenju da su određen i „,negativni” oblici ponašanja izraženiji upravo jer njihova manja uključenost ograničava njihovu senzitivnost u prepoznavanju inteziteta detetovih reakcija i ponašanja. Otac koji je manje uključen u brigu tako će možda određene stavke kao što su: dete saopštava šta želi, dete izgeda razdražljivo, reaguje na vašu pažnju, neuobičajeno je naporno, na male stvari reaguje plačem, oceniti kao učestale oblike ponašanja samo zato što ih njegova manja uključenost vodi većem nerazumevanju deteta i njegovog tipičnog ponašanja. Čini se da regulatorsko ponašanje može da bude povezano sa očevom slikom o detetovom funkcionisanju odnosno procenom ograničenosti detetove sposobnosti da učestvuje u svakodnevnim aktivnostima u odnosu na mentalni i fizičko zdravlje i/ili invalidnost. Sa druge strane, moguće je i da je potreba majki da regulišu i dominiraju brigom nad detetom sa realno nižim funkcionalnim statusom izraženija, što ukazuje na procese unutar porodičnog prilagođavanja na niži funkcionalni status deteta kao odgovor na razvojne ili nerazvojne stresne procese. Istraživanja u inostranstvu ukazuju na pravilnost da senzitivnost očeva zaista korelira sa njihovom uključenošću, te da će veštiji u prepoznavanju signala, potreba i razvojnih mogućnosti svog deteta (na predškolskom uzrastu), zaista biti uključeniji očevi (Volling \& Belsky, 1992; Easterbrooks \& Goldberg, 1984). Takođe, istraživanja beleže značajnu tendenciju da prisustvo i uključenost očeva u brigu o detetu, u ranom detinjstvu, zaista diže kapacitete deteta da se prilagođava, 
smanjuje izraženost distresa, te da su ovi efekti vidljivi kontinuirano kroz odrastanje deteta do odraslog doba (Fluori \& Buchanan, 2003).

Rezultati istraživanja otvaraju značajna pitanja za dalji rad u oblasti porodičnih činilaca i funkcionalnosti deteta. Određena ograničenja ovog istraživanja potiču od samog načina na koji je detetovo blagostanje i funkcionalnost operacionalizovano. Moguće je da smo odabirom instrumenta koji dominantno razlikuje decu sa ozbiljnim teškoćama ili razvojnim smetnjama od dece optimalnog ili prosečnog razvojnog toka, ograničili mogućnost registrovanja promena u funkcionisanju koje su izazvane kontekstom razvojne krize kakav je polazak u vrtić. S tim u vezi, dobijena mala varijansa vrednosti procena funkcionalnog statusa deteta može biti posledica strukture uzorka u kojem je značajno manji broj dece sa hroničnim oboljenjem ili invaliditetom koja su uključena u redovne predškolske ustanove. U tom smislu za dalja istraživanja preporučujemo uključivanje i drugih mera prilagođavanja i zdravlja deteta, kao i uključivanje dece sa hroničnim smetnjama i invaliditetom u uzorak. Konačno, longitudinalne studije bi dale uvid u to da li i kojim procesima se manje funkcionalni oblici koroditeljske saradnje razvijaju kao posledica smanjenog funkcionisanja deteta i time izazvanog generalnog stresa, ili su i kada, već prethodno razvijeni kao loši, pa doprinose još niže funkcionalnom ponašanju deteta. Takođe, možda su dobijeni nalazi povezani sa uzrastom dece, pa bi relacija između ovih varijabli izgledala drugačije u porodicama starije dece.

Dobijeni nalazi ukazuju na značaj rada na koroditeljskoj saradnji i jačanju funkcionalnijih oblika odnosa među roditeljima, u smislu prevencije regulatorskog ponašanja majki što bi dalje vodilo većoj senzitivnosti i očeva i majki, te boljoj $\mathrm{i}$ kvalitetnijoj brizi o detetu.

\section{LITERATURA}

Abidin, R., R., Bruner, F., J. (1995). Development of a Parenting Alliance Inventory. Journal of Clinical Child Psychology, 24, 1, 31-40.

Allen, S.M., Hawkins, A.J. (1999). Maternal gatekeeping: Mothers' beliefs and behaviors that inhibit greater father involvement in family work. Journal of Marriage and Family, 61, 199-212.

Belsky, J., Putnam, S., Crnic, K. (1996). Coparenting, Parenting, and Early Emotional Development. New Directions for Child and Adolescent Development, 74, 45-55.

Belsky, J., Bell, B., Bradley R., H., Stallard, N., Stewart-Brown, S. L. (2006). Socioeconomic risk, parenting during the preschool years and child health age 6 years. European Journal of Public Health, 17, 5, 508-513.

Belsky, J., Vandell, D., L., Burchinal, M., Clarke-Stewart, K., A., McCartney, K., Owen, M., T. (2007). Are There Long-Term Effects of Early Child Care? Child Development, 78, 2, 681-701.

Cannon, E., Schoppe-Sullivan, S., Mangelsdorf, S., Brown, G., Sokolowski, M. (2008). Parent characteristics as antecedents of maternal gatekeeping and fathering behavior. Family Process, 47(4), 501-519. 
Conger, D., R., Conger, J., K., Elder, H., G, Lorenz, O., F., Simons, L. R., Withbeck, B., L. (1992). A Family Process Model of Economic Hardship and Adjustment of Early Adolescent Boys. Child development, 63, 3, 526-541. doi: 10.1111/j.1467-8624.1992.tb01644.x

De Luccie, M. (1995). Mothers as gate-keepers: a model of maternal mediators of fathers involvment. Journal of Genetic Psychology, 156(1), 115-131.

Easterbrooks, M. A., Goldberg, W. (1984). Toddler development in the family: impact of father involvement and parenting characteristics. Child Development, 55, 740-752.

Erdeš - Kavečan , Đ. (2009). Roditeljski savez i njegove relacije sa komponentama psihofizičkog zdravlja deteta. Primenjena psihologija, 2, 3, 287-302.

Garner, R., E., Arim, R., G., Kohen, D., E., Lach, L., M., MacKenzie, M., J., Berhaut, J., C., Rosenbaum, P., L. (2011). Parenting children with neurodevelopmental disorders and/or behaviour problem. Child: care, health and development, 39, 3, 412-421. doi: 10.1111/ j.1365-2214.2011.01347.x2011347

Gaunt, R. (2008). Maternal gatekeeping: antecedentes and consequences. Journal of Family Issues, 29(3), 373-395.

Geddes, H. (2008). Reflections on the role and significanceof fathers in relation to emotional development and learning. British Journal of Guidance \& Counselling, 36, 399-409.

Fagan, J., Barnett, M. (2003). The relationship betweeen maternal gate-keeping, paternal competence, mother attitudes about the father role and father involvment. Journal of Family Isuess, 24(8), 1020-1043.

Feinberg, M.,E. (2003). The Internal Structure and Ecological Context of Coparenting: A Framework for Research and Intervention. Parenting: science and practice, 3, 2, 95-131.

Fluori, E., Buchannan, A. (2003). The role of father involvement in children later mental health. Journal of Adolescence, 26, 63-78.

Konold, T., R., Abidin, R., R. (2001). Parenting Alliance: A Multifactor Perspective. Assessment, 8, 1, 47-65. doi: 10.1177/107319110100800105

Lerpoy, M., Mahoney, A., Demaris, A., Pargamnet, K. (2013). Longitudinal links betwen early coparenting and infant behaviour problems. Early child development and care. $183,3 / 4,360-377$.

Margolin, G., Gordis, E. B., \& John, R. S. (2001). Coparenting: A link between marital conflict and parenting in two-parent families. Journal of Family Psychology, 15, 3-21.

Mc Bride, B., Rane, T. (1998). Parenting alliance as a predictor of father involvement: an explanatory study. Family Relations, 47, 229-236.

Mihić, I. (2006). Značaj uverenja o roditeljskim ulogama kao činilaca kvaliteta roditeljstva. Magistarski rad. Novi Sad: Filozofski fakultet.

Mihić, I., Zotović, M., Petrović, J. (2007). Koroditeljski odnosi: prikaz dva instrumenta za merenje roditeljske saradnje. u: M. Biro, S. Smederevac (ur). Psihologija i društvo. Novi Sad: Odsek za psihologiju, Filozofski fakultet.

Mihić, I. (2009a). Snaga roditeljskog saveza. Psihološka procena porodice: Mogućnosti i ograničenja, 90-98.

Mihić, I., Zotović, M., Petrović, J., Avić, B. (2009b). Vaspitni procesi u porodici: Povezanost kvaliteta dijadnih i trijadnih odnosa. Zbornik Instituta za pedagoška istraživanja, 1, 100-115.

Mihić I. (2010a). Činioci uključivanja oca u brigu o detetu. Doktorska disertacija, Filozofski fakultet, Novi Sad.

Mihić, I. (2010b). Uključenost oca u brigu o detetu: Efekti očevih iskustava iz porodice porekla i kvaliteta relacija u porodici prokreacije. Primenjena Psihologija, 3, 197-222. 
Mihić I. (2010c). Efekti regulatorskog ponašanja majke na uključenost oca u brigu o detetu predškolskog uzrasta. Zbornik institute za pedagoška istraživanja, 42, 277-291.

Miljković, M., Srna, J. \& Mićović, R. (1997). Porodična terapija. Beograd: Centar za brak i porodicu.

Minić, J. (2009). Porodica u krizi. Zbornik radova Filozofskog fakulteta u Prištini, 39, 425-435.

Minuchin, P. (1985). Families and individual development: Provocations from the field of family therapy. Child Development, 56, 289-302.

Palermo, M., T., Long, C., A., Lewandowski, S., A., Drotar, D., Quittner, L., A., Walker, S., L (2008). Evidence-based Assessment of Health-related Quality of Life and Functional Impairment in Pediatric Psychology. Journal of Pediatric Psychology, 33, 9, 983-996. doi: 10.1093/jpepsy/jsn038

Sarkadi A., Kristiansson R., Oberklaid, F., Bremberg, S. (2007). Fathers' involvement and children's developmental outcomes: A systematic review of longitudinal studies. Acta Pædiatrica, 97, 153-158.

Stein, K., E., R., Jones, D. (1990). Functional Status II(R): A Measure of Child Health Status. Medical Care, 28, 11, 1041-1055.

Stojić, O., Divljan, S., Avramov N. (2010). Adaptacija dece jaslenog uzrasta u kontekstu teorije afektivne vezanosti: iskustva predškolskih ustanova Srema. Primenjena psihologija, 2, 357-376.

Teubert, D., Pinquart, M. (2010). The Association Between Coparenting and Child Adjustment: A Meta-Analysis. Paretnig: Sience and practice, 10, 286-307. doi: 10.1080/15295192. 2010.492040

Vandell, D., L., Belsky, J.,, Burchinal, M., Steinberg, L., Vandergrift, N. (2010). Do Effects of Early Child Care Extend to Age 15 Years? Results From the NICHD Study of Early Child Care and Youth Development. Child Development., 81, 3, 737-756.

Velikić, D., Filipović, B., Bačić, J., Bogosanović, B. (2010). Relacije socioemocionalne posvećenosti majki sa prilagođenošću deteta na vrtić. Primenjena psihologija, 4, 323-335.

Volling, B., Belsky, J. (1992). The contribution of mother-child and father-child relationships to the quality of sibling interaction: a longitudinal study. Child Development, 63, 1209-1222.

Mihić Ivana, Damjanović Dajana, Radovanović Mila

\section{RELACIJE KVALITETA RODITELJSKOG SAVEZA I FUNKCIONALNOG STATUSA DETETA: PROCENA OČEVA I MAJKI}

\section{REZIME}

Značaj kvaliteta koroditeljske saradnje za razvoj i blagostanje deteta potvrdile su brojne studije. Pored individualnih karakteristika roditeljstva, odnosno roditeljskog ponašanja, istraživanja su ukazala na značaj kvaliteta relacije među roditeljima za detetov razvoj, ponašanje, blagostanje i prilagođavanje u situacijama stresa. Ovaj rad bavi se relacijom kvalitetata koroditeljske saradnje i funkcionalnog statusa dece predškolskog uzrasta. Kvalitet koroditeljske saradnje operacionalizovan je preko snage roditeljskog saveza i regulatorskog ponašanja majke. Cilj istraživanja bio je da se opiše veza između procena snage roditeljskog saveza i regulatorskog ponašanja majki sa procenama detetovog funkcionalnog statusa od strane majki i očeva. Istraživanje je sprovedeno u predškolskim ustanovama i obuhvatilo je porodice dece koja su u godini kad je rađeno istraživanje 
po prvi put pošla u vrtić. Opredeli smo se za ovakav uzorak, jer polazak u vrtić predstavlja razvojnu krizu i može značajno da menja porodične odnose i funkcionisanje deteta. Dobijeni rezultati su pokazali da nema razlike između majki o očeva kada je u pitanju procena snage roditeljskog saveza, te da i majke i očevi procenjuju da imaju dobar koroditeljski odnos sa partnerom. Takođe, nisu nađenje značajne razlike u proceni funkcionalnog statusa deteta. Pretpostavka da će snaga roditeljskog saveza biti značajno povezana sa funkcionalnim statusom deteta nije potvrđena dobijenim nalazima. Ipak, regulatorsko ponašanje majki, kao specifičan oblik funkcionisanja unutar roditeljskog saveza, pokazalo se značajnim za funkcionalni status deteta u poduzorku očeva. Dobijeni nalazi otvorili su važna pitanja za dalji radu u oblasti porodičnih činilaca i funkcionalnosti dece.

Mihić Ivana, Damjanović Dajana, Radovanović Mila

\section{RELATIONS BETWEEN QUALITY OF PARENTING ALLIANCE AND CHILD'S FUNCTIONAL STATUS: MATERNAL AND PATERNAL ASSESSMENT}

\section{SUMMARY}

The research presented in this paper aimes to describe relations between quality of parenting alliance (defined by coparenting quality and maternal gatekeeping behavior) and child's functional status in the families with preschool children. The quality of all relations has been assessed by both mothers and fathers of children who entered preschool in this academic year.

Results indicate significance of the quality of coparenting relations as protective factor for maternal gatekeeping, leading to greater levels of parental sensitivity and quality of child care in families.

Kew words: parenting alliance, coparenting, maternal gatekeeping behavior, functional status of the child 